\title{
CHALLENGES OF DIFFERENTIATED AND INDIVIDUALIZED TEACHING IN VOCATIONAL EDUCATION: THE CASE OF SLOVENIA
}

\section{Klara Skubic Ermenc, Damijan Štefanc, Jasna Mažgon}

University of Ljubljana, Slovenia

E-mail: klara.skubic-ermenc@ff.uni-lj.si, damijan.stefanc@ff.uni-lj.si,

jasna.mazgon@ff.uni-lj.si

\begin{abstract}
One of the main factors contributing to students' optimal development in school settings is the implementation of appropriate differentiating and individualizing measures. While this topic is well researched and addressed in the context of primary and lower secondary education, the theoretical and empirical research on differentiated and individualized teaching in vocational education and training (VET) programs is relatively scarce. However, well-applied individualization measures seem equally important in the context of VET programs, as they are frequently attended by students with lower educational aspirations, diverse socio-cultural backgrounds, and complex educational and personal needs. Our research explores what kind of individualization practices exist in Slovenian VET programs and what roles teachers and school management play in implementing individualized teaching. A single case study with one class of 16-year-old students $(N=22)$ attending the confectioner VET program was conducted. The data were collected by means of interviews, observations, and questionnaires, and were analyzed and interpreted by combining qualitative and quantitative methodological approaches. The results indicate that the school strove to address the diversity of the student population and used a number of different activities at institutional (school) as well as individual (teacher) levels. However, the potential of a more individualized approach seems to be largely unexploited. It is necessary to understand individualization as a principle implemented at the level of direct teaching and at the school level. Students should receive guidance that adapts the education process to their individual characteristics and aspirations as much as possible.
\end{abstract}

Keywords: differentiated teaching, individualized teaching, school management, Slovenia, vocational education

\section{Introduction}

Fostering the students' optimal development primarily takes place by implementing the principle of individualization, which requires schools and teachers to plan and implement the educational process in a way that gives each individual student the opportunity to acquire knowledge and develop their abilities and personality traits as best they can. Doing so relies not only on the individual student's learning ability but also on their individual interests and needs (Dixon et al., 2014; Gregory \& Chapman, 2002; Strmčnik, 2001; Subban, 2006; Tomlinson, 2001; Wang, 1984). Individualization is a didactic principle that requires schools and teachers to adapt classroom teaching and learning to the individual educational and learning characteristics, needs, aspirations, and inclinations of each student, allowing them to learn as independently 
Klara SKUBIC ERMENC, Damijan ŠTEFANC, Jasna MAŽGON. Challenges of differentiated and individualized teaching in vocational education: The case of Slovenia

PROBLEMS

OF EDUCATION IN THE $21^{\text {st }}$ CENTURY Vol. 78 , No. 5, 2020

816

as possible (Strmčnik, 1987, p. 12). As such, individualization serves as one of the factors influencing the choice of organizational and instructional approaches. From the organizational viewpoint, it has to be embedded into a particular differentiation model. When occurring within the school or particular classroom and students are subdivided into several groups according to their distinctive features (e.g., learning abilities), such differentiation is called intrinsic or didactic (Lamanauskas, 2009, p. 6).

Although they are two different concepts, individualization and differentiation are closely related because putting individualization into practice always presupposes some form of differentiation. Generally speaking, a distinction can be made between organizational and formal differentiation (Le Tendre et al., 2003), which refers to differentiation among different types of schools, i.e., between vocational and academic upper secondary schools, and curriculum differentiation, which takes place at the school level. Curriculum differentiation denotes "a process whereby students are divided into categories so that they can be assigned in groups to various kinds of classes. [... Students are often] placed into fast, average, or slow classes" (Oakes, 2005, p. 3). Organizational and curriculum differentiation have long been targets of severe criticism due to their unfavorable effects: early studies indicated their unfavorable effects on learning achievements, while contemporary studies focus primarily on their negative impact on equity of education (Cankar et al., 2017; Dupriez, 2010; Field et al., 2007; Oakes, 2005; Slavin, 1987, 1990; Willms, 2006). As early as 1987, Slavin concluded that "The use of ability grouping may serve to increase divisions along class, race, and ethnic group lines" (1987, p. 297). Differentiation has been criticized as a key mechanism that strengthens the system's social-reproduction role, yet it can also serve to lessen this role and improve education equity, provided that it is organized as a flexible mechanism (Dupriez, 2010).

From the equity perspective, vocational education can have a controversial role: since it attracts people from different social backgrounds, including those who face obstacles in learning, it plays a positive, social-integrative role. However, it also has the opposite effect and strengthens the system's social-reproduction role, particularly in societies that do not value vocational education and where vocational qualifications do not lead to valuable and decently paid jobs (Medveš et al., 2008). At the institutional level, several differentiation models supporting the individualization principle can be devised (Analiza dobrih praks, 2010; Arduin, 2015; Humphrey et al., 2013; Kubat, 2018), including ability (or part-time ability) grouping for selected subjects and different models of within-class ability grouping (Slavin, 1987; Strmčnik, 1987).

\section{Vocational Education in Slovenia: Some Contextual Aspects}

The current design of the VET system in Slovenia was established in 1992, shortly after Slovenia gained independence. The system is characterized by the following three types of educational programs:

- Lower VET programs lead to occupations at the level of assistant or ancillary staff and take two years to complete. A student who successfully finishes the program is eligible to matriculate into the first year of a three-year secondary vocational program.

- Three-year secondary VET programs train students to take on occupations at the level of skilled workers, craft, and the service sector, while having a pronounced general education component, as the graduates are able to enroll in an additional two-year vocational and technical education program. The latter program is already at the level of technical/professional education and is therefore completed with the vocational matura. The matura enables students to be trained in an occupation at the level of a technician, while providing for unlimited matriculation into vocational colleges and higher education programs.

- Four-year secondary technical education programs conclude with the vocational matura. 
Ever since the first VET reform in 1992, the main aims were to establish vocational education on the principle of social partnership to ensure basic VET for all and to set up a complete educational ladder allowing vertical transferability within each occupational field (all the way up to tertiary education level) as well as transferability between vocational and general education (Medveš \& Muršak, 1992). In 2001, new guidelines for the Elaboration of Educational Programs in Lower and Secondary VET were published. These guidelines led to the introduction of competency-based and modular programs, which allowed technical module classes and practical classes to be more closely intertwined and encouraged lessons based on project- and problem-based education. The guidelines also encouraged schools to connect the theory and practice lessons through the participation of teachers in the planning and implementation of lessons (Ermenc, 2009, 2011).

\section{Contemporary Challenges of Vocational Education in Slovenia}

The research focuses on three-year secondary VET programs and the situation vocational schools in Slovenia face today. These schools are often part of large school centers that offer all the aforementioned types of educational programs, including general upper secondary programs. Following several years of decline, enrolment in secondary VET programs has been on a slow increase since the 2010/2011 academic year (at a time when Slovenia was hit by the recession), and in 2017/2018, a little over 23\% of all Year 1 students were enrolled in VET programs (MIZŠ, 2019). However, despite increased enrolment, these programs are the least attractive programs in Slovenian upper secondary education. According to Cankar et al. (2017), the socioeconomic status of students who are enrolled in vocational schools is markedly unequal, i.e., different parental educational attainment, different parental income and assets, and different cultural capital:

The SES of students in upper secondary education does not explain any variability $(0 \%)$ in the achievement within a school, it does, however, explain the high variability (i.e. $78.6 \%$ ) in achievements of different schools. Slovenian general upper secondary programmes are attended by students who, in terms of their SES, are in a markedly privileged position in comparison with students in four-year secondary technical education programmes, and even more so compared to students in VET programmes. With its composite effect, the inclusion of an individual student in a group of classmates from a privileged socioeconomic and cultural environment on the one hand, and a student who is grouped with classmates from a disadvantaged socioeconomic and cultural environment on the other further contributes to the reproduction of social inequality. (p. 9)

Moreover, such programs are also attended by the majority of newly immigrated young people (Vižintin, 2017). For students with special educational needs, the situation is somewhat specific: in recent years, the number of students with a statement of special educational needs has increased in all programs, especially at the expense of students who have deficits in certain areas of learning and whose statements include several identified disabilities (MIZŠ, 2019). It is, however, important to note that the share of students with special educational needs in lower VET programs that are intended for these students ${ }^{1}$ decreased between 2010 and 2017; i.e., in 2017, they amounted to a little over $31 \%$, and seven years later, they had dropped to a little over $20 \%$. By contrast, in other programs, the share of students with a statement of special educational needs increased, i.e., in three-year secondary VET programs, they amounted to a little over $10 \%$ in 2010 , increasing to $14.5 \%$ in 2017 ; in four-year secondary technical education programs, their percentage was $2.5 \%$ in 2010 and a little over $6 \%$ seven years later. In other words, three-year secondary VET programs have partly taken over the "tasks" that were not so long ago typically performed by lower VET programs. However, they also attract individual students with special interests and talents (Belasić \& Čop, 2020). Nevertheless, in

\footnotetext{
$1 \quad$ These programmes can be attended by students who have successfully completed at least seven years of primary
} school or a primary school for students with a mild mental disability.

\begin{tabular}{|l} 
PROBLEMS \\
OF EDUCATION \\
IN THE 21 $1^{\text {st }}$ CENTURY \\
Vol. 78, No. 5, 2020 \\
\hline 817
\end{tabular} 
Klara SKUBIC ERMENC, Damijan ŠTEFANC, Jasna MAŽGON. Challenges of differentiated and individualized teaching in vocational education: The case of Slovenia

PROBLEMS

OF EDUCATION

IN THE $21^{\text {st }}$ CENTURY Vol. 78 , No. 5, 2020

818

vocational education, the number of such students is low, as parents who have a strong influence on students' decisions are not favorably disposed to vocational education (CEDEFOP, 2017). Teachers are often not motivated to work in these schools and do not have high expectations of students (Kroflič et al., 2009). Even though vocational education has been conceived as inclusive, high-quality education, based on the idea of lifelong learning, it strengthens the socio-reproductive role and is veering away from its fundamental goals. As such, schools face major professional challenges in their day-to-day work, as they have to carry out educational programs in a climate that is less favorable to learning and for students who have not only poor prior knowledge, underdeveloped learning strategies, and low motivation (Bren et al., 2017), but also a number of personal, family-related, and financial hardships (Belasić \& Čop, 2020; Poročilo o spremljanju, 2008).

\section{Individualization as a Fundamental Principle of Vocational Schools' Work}

The most important elements for improving the situation described above are systemic measures. However, systemic measures alone are not enough to solve all the problems, as full inclusion in upper secondary education-for which something that every democratic society must strive-always brings with it the diversity of the population included in the education. The needs of such a population need to be responded to at the curricular and institutional levels. In other words, a democratic society also necessitates schools and teachers assuming responsibility for (more) inclusive and individualized execution of the education process, which is the topic of the present research. In terms of differentiation, it is necessary to consider the following principles (Bushie, 2015; Deunk et al., 2018; Dixon et al., 2015; Strmčnik, 1999; Tomlinson, 2001):

1) Teaching must meet the collective and individual needs of students within each program; schools must therefore not treat students as if they were all the same, nor should they separate them in terms of space and time for too long.

2) Differentiated teaching must be implemented in a way that benefits all students, i.e., in a way that makes sure it does not diminish individual student differences, and differentiation-related activities must contribute to the optimal development and achievement of the learning goals of each individual student.

3) Schools must therefore alleviate the socially conditioned learning differences and provide all students with equal opportunities for their optimal development.

In vocational education, differentiation and individualization play an important role in the development of students' vocational competencies, which makes them indispensable in competency-based programs for achieving the students' broad professional qualification (Muñoz Martínez \& Porter, 2018; Solberg, 2012).

\section{Research Problem and Research Questions}

For several years now, the Institute of the Republic of Slovenia for Vocational Education and Training in cooperation with the researchers of the Department of Educational Sciences at the Faculty of Arts, University of Ljubljana, has been conducting research on the topic of individualization in vocational upper secondary education (Belasić \& Čop, 2020). The research questions were:

RQ1. Is the principle of individualization understood as one of the fundamental principles of pedagogical work at vocational schools, and how was this principle reflected in the schools' basic documents and guidelines?

RQ2. What role does school management play in implementing and promoting individualized teaching? 
Klara SKUBIC ERMENC, Damijan ŠTEFANC, Jasna MAŽGON. Challenges of differentiated and individualized teaching in vocational education: The case of Slovenia

RQ3. What are the didactic features of lessons in the programs included in the project, and to what extent has the existence of internal differentiation and individualization been observed in lessons?

RQ4. What have students observed regarding the implementation of the principle of individualization, and how satisfied are they with the choice of the program?

\section{Research Methodology}

\section{General Background}

This study used mixed methods research design, combining qualitative and quantitative methodological approaches. The qualitative part of the research involved the collection and analysis of data based on interviews and observations, while the quantitative part of the research involved the collection and analysis of numeric data. A single case study was conducted as a research design, which "allowed researchers to dig deeply into the details of the case in order to develop a rich, complex, and compelling argument" (Brancati, 2018, p. 120).

The presented case study refers to a confectioner program taught at a school of food processing that is part of a large school center in an urban area of Slovenia. The school center offers various programs from the field of food and hospitality, covering a full range of VET programs from ISCED 3 to ISCED 5. For a more in-depth analysis, a class consisting of 22 students attending a secondary VET program was selected.

\section{Sample}

The research included various stakeholders, namely four experienced teachers (two teaching technical module classes and two teaching practical classes, who have been teachers for an average of 17 years), a head teacher (HT), and a school counselling service ${ }^{2}$ (a school psychologist and a social worker). The research also included the students of a Year 1 class $(N=22)$, aged between 15 and 16 . The class consisted of 18 girls and four boys, 20 of whom were born in Slovenia (the language they speak at home is Slovenian) and two were born in another country but have lived in Slovenia for two years (at home, they speak a language other than Slovenian). The educational attainment of the students' mothers was low; most of them had vocational or technical secondary education (a little under 73\%), 4.5\% had completed or partially completed primary education, one had completed a general upper secondary education program, two had higher vocational education and higher education, and for two mothers, the students were unable to give an answer. The families' low SES is indicated by the data on the number of books the families own: most families (approx. 45\%) owned up to 25 books, a little over $18 \%$ of the families owned up to 50 books, and the same percentage applies to families that owned up to 100 and 200 books. No families own more than two hundred books. Ethical principles were also considered throughout the study: although the research did not contain any ethically highly sensitive procedures, the anonymity of participating teachers and students was preserved and their participation in all parts of the study was strictly voluntary. Since the students were minors at the time when research was conducted, their parents signed a written consent form for them to be able to participate.

2 In Slovenian primary and secondary education, each school has its own in-school counselling service. The number of counselling service members at a school depends on the number of students enrolled in the school (usually two to three professionals from the fields of pedagogy, psychology, or social work).

\begin{tabular}{l} 
PROBLEMS \\
OF EDUCATION \\
IN THE 21 $1^{\text {st }}$ CENTURY \\
Vol. 78, No. 5, 2020 \\
\hline 819
\end{tabular} 
Klara SKUBIC ERMENC, Damijan ŠTEFANC, Jasna MAŽGON. Challenges of differentiated and individualized teaching in vocational education: The case of Slovenia

PROBLEMS

OF EDUCATION

IN THE $21^{\text {st }}$ CENTURY

Vol. 78, No. 5,2020

820

\section{Instrument and Procedures}

The triangulation of the following techniques was used for data collection:

- A student questionnaire was administered, which contained closed-ended questions, Likert scales, and assessment scales. The statistical analysis showed that the scales were reliable (Cronbach's coefficient $\alpha \geq 0.80$ ) and valid (for construct validity, confirmatory factor analysis was used to test the extent to which the data from our survey is a good representation of our theoretical understanding of the construct. The first factor explained more than $20 \%$ of the variance). Content validity was assessed qualitatively by an expert and three practitioners checking that the survey contained questions that covered all aspects of the content being measured. In this article only part of the data collected with the questionnaire are presented.

- A semi-structured interview was conducted with the HT, which included questions about her views on the importance of individualization and an assessment of how individualization is implemented in the institution of which she is in charge.

- Structured non-participant observation was performed separately by two qualified observers using observation protocols; observations took place in three different technical modules (a 90-minute one and two 45-minute ones); the protocol for observing the use of teaching strategies required the observer to record at five-minute intervals which type of social organization of learning activities (frontal teaching, group work, pair work, individual work) and which teaching method (explanation, discussion, demonstration, experiment, practical work, use of audio-visual materials, text-based activities) the teacher was using at the time. During each interval, the observers also noted the use of a combination of different types of social organization of learning activities and teaching methods if the teacher was using more than one at that time. The protocol allowed the observers to record any other relevant observations (didactic materials used, students' activity, and other notes) to be used for a qualitative lesson analysis at a later time.

- A preliminary questionnaire for the HT and the two school counsellors, which included questions about how students' specific characteristics are taken into account at the school during the academic year planning stage, how teachers are supported and encouraged, and whether team planning and team teaching are encouraged (e.g., in the form of project work).

- A non-standardized, open-ended interview with the teachers was conducted after the observed lessons, which allowed the teachers to provide additional arguments in support of their choices and actions during the observed lessons.

\section{Data Analysis}

For the processing and presentation of quantitative data, frequency tables ( $f$ and $f \%)$ were used for the most part. The data collected by means of interviews and observation protocols were processed according to the principles of qualitative content analysis. The collected data were first compiled in the basic register and were then transcribed. Coding units were selected, and the data were coded. Lastly, codes were grouped into categories that allowed further interpretations (Brancati, 2018).

\section{Research Results}

\section{Implementation of the Principle of Individualization at the School Level}

The interview with the HT and an analysis of the preliminary questionnaire revealed that, at the school, individualization is understood as a measure that is implemented at the level of 
Klara SKUBIC ERMENC, Damijan ŠTEFANC, Jasna MAŽGON. Challenges of differentiated and individualized teaching in vocational education: The case of Slovenia

PROBLEMS

OF EDUCATION

IN THE $21^{\text {st }}$ CENTURY

Vol. 78 , No. 5, 2020

individual classes and teachers. The school's vision therefore does not refer to individualization explicitly; however, some individualization elements can be noticed in the annual work plan. 821 The HT explained that the population at their school is very diverse, which, in the HT's opinion, requires constant adaptations and individualization:

Quite a few students have low achievement, they come from different social backgrounds;... some even have to take care of their families at home; ...we've seen an increase in young people who have mental health issues;... and then there are foreigners; ... and we also have students who were A-students in primary school and have a lot of potential. (HT)

The school develops annual plans for the work with students who have a statement of special educational needs or are hospitalized and organizes Slovenian language courses for immigrant students (funded by the Ministry of Education, Science and Sport). Other activities that reflect the implementation of the principle of individualization are planned whenever necessary, depending on the needs: they provide learning support to students who are preparing to retake exams or working on getting a pass mark. Learning support is provided by teachers, especially during marking periods.

At our school, we also have mentoring for students who have difficulty learning or struggle how to get organized for learning - there are teachers available to them. The teachers do this on a voluntary basis; the focus is on students learning how to learn, how to get organized, how to get better marks, etc. (HT)

For more able students, the school takes care of them by including them in various national and international competitions. For interested students, the school organizes mobility, such as work experience in companies in other countries, which suggests that systematic and pre-planned support is primarily geared towards students from the most vulnerable groups. For other students, greater emphasis is placed on responding whenever necessary and taking corrective action.

\section{The Role of School Management in the Implementation of Individualization}

When asked about the way they encourage teachers to implement individualization and how it could be strengthened even further, the HT explained that special attention is devoted to supporting class teachers ${ }^{3}$. Being a class teacher is considered a great challenge, and class teachers are therefore encouraged to organize "themed class meetings because they strengthen the class teacher's interaction with students. We have workshops on strengthening social skills, etc." (HT). Some class teachers conduct individual student consultations; some keep individual records. The HT pointed out:

"Our school is a vocational school and the students have it anything but easy. They have to be employed and attend school at the same time. The fact is that we adapt the program to these students." (HT)

The school also encourages peer support so that, for instance, students with immigrant experience help newly immigrated students. However, the school also wants to devote more attention to more able and highly motivated students.

The school encourages teacher teamwork so that teachers share knowledge and experience. Teachers share knowledge with one another by means of shared online classrooms, and thematic conferences, where teachers can present examples of good practice, are also organized occasionally. The school works with companies where students do compulsory

3 In the Slovenian school system, each class of students has a teacher who performs the role of the students' administrative and pedagogical leader, thus taking care of the administrative and teaching aspects of classroom management (cf. Kalin, 2001). 
Klara SKUBIC ERMENC, Damijan ŠTEFANC, Jasna MAŽGON. Challenges of differentiated and individualized teaching in vocational education: The case of Slovenia

PROBLEMS

OF EDUCATION IN THE $21^{\text {st }}$ CENTURY Vol. 78, No. 5, 2020

work experience; however, they work more closely with companies that are willing to take on students with special educational needs because mentors in companies often lack the required knowledge to work with such students.

Regarding how many students in individual programs have a personal education plan (PEP) and the most common reasons for having one, no exact figures regarding were obtained because the school does not keep any comprehensive records. However, the reasons PEPs were prepared were listed in the preliminary questionnaire. The most common reason is a statement of special educational needs-if a student has one, a PEP is a statutory requirement. In addition, PEPs are prepared for students who have many failing marks, for immigrant students (according to the law, they are entitled to assessment accommodations for two years after immigrating to Slovenia), when a student transfers from another school or program and when instructional accommodations are needed for students after lengthy hospitalization. Of the students who were asked if they had a PEP-a quarter answered in the affirmative-which corresponds with the school's assessment.

\section{Didactic Features and the Presence of Internal Differentiation and Individualization}

An "Observer as Participant" type of classroom observation was used to identify the didactic features of the lessons in the program that were part of the project and to determine the extent to which the presence of internal differentiation and individualization has been observed in the lessons. Tables 1 and 2 show that all four types of social organization of learning activities and six teaching methods were observed in the classroom.

\section{Table 1}

The use of various types of social organization of learning activities ( $N=$ number of observed events ${ }^{4}$ )

\begin{tabular}{ll}
\hline Types of social organization of learning activities & $\boldsymbol{N}(\%)$ \\
\hline Frontal Teaching & $12(33.3)$ \\
\hline Individual Work & $6(16.7)$ \\
\hline Group Work & $6(16.7)$ \\
\hline Pair Work & $12(33.3)$ \\
\hline Total & $36(100.0)$ \\
\hline
\end{tabular}

Table 2

The use of various teaching methods ( $N=$ number of observed events)

\begin{tabular}{lll}
\hline Teaching Methods & $\mathbf{N}$ & $\%$ \\
\hline Explanation & 8 & 21.1 \\
\hline Discussion & 3 & 7.9 \\
\hline Demonstration & 5 & 13.2 \\
\hline Experiment & 0 & 0.0 \\
\hline Practical Work & 11 & 28.9 \\
\hline Use of AV Materials & 6 & 15.8 \\
\hline Text-Based Activities & 5 & 13.2 \\
\hline Total & 38 & 100.0 \\
\hline
\end{tabular}

4 The observers recorded the data by noting down separately which types of social organisation of learning activities (Table 1) and which teaching methods (Table 2) the teacher was using at a given moment. They did so at regular five-minute intervals. The $N$ therefore represents the number of observed events. 
Klara SKUBIC ERMENC, Damijan ŠTEFANC, Jasna MAŽGON. Challenges of differentiated and individualized teaching in vocational education: The case of Slovenia

Data recording took 180 minutes, i.e., four 45-minute lessons, which revealed the frequency of the use of individual types and methods, as presented in Tables 1 and 2. The observers noted the predominant use of frontal teaching and pair work and to a lesser extent individual and group work. The most frequently observed didactic event was the use of practical work (because half of the classroom observation took place during practical classes), followed by an explanation and use of AV materials. The descriptions below link the results of the classroom observation with the interview conducted with the teacher after the class.

\section{The First Observed Teaching Unit: Practical Class}

The practical class took place in a school workshop and lasted 90 minutes. The classroom work was highly intensive. At the beginning of the lesson, the teacher (T1) gathered the students and explained the technological procedure that they would be following. She referred to the knowledge gained during the technical module class and repeated the instructions on occupational safety, equipment handling, and hygiene. The students were divided into pairs, each receiving their own set of work instructions, which varied according to the complexity of the procedure. The procedure complexity was thus the starting point for internal differentiation and the basis for differentiation in terms of knowledge standards: two students worked independently on a complex procedure that corresponded to the level of an international competition, while two other students practiced only the basic procedure. The teacher said the students in the class are very diverse, i.e., two students won the first prize in an international competition, while some of them have below-average intellectual capabilities and manual dexterity. For this reason, the teacher adjusted the learning pace, i.e., for more able students, she prepared additional, more challenging tasks in advance, such as those requiring students to convert and adjust recipes for special diets. During the lesson, she got all the students together twice, commenting on common mistakes and giving additional explanations. She tried to find a balance between individual work, pair work, and group work. The students worked independently under her watchful eye. She pointed out their mistakes and discussed the reasons for any problems they were having and how to deal with them. Differentiation was thus also reflected in the degree of independence she entrusted her students with. If she noticed one of the students not knowing what to do next, she guided them step by step or with questions. She encouraged her students by saying, "Use the internet and find..." and "Well done, this is how you start. Do you remember... do you know how to do it?" After the lesson, she stated the following:

I usually know the students very well after a single month... I know exactly who I can trust to make something from start to finish and who I have to keep any eye on the whole time. I guide them individually when I see how they go about their work as individuals. (T1)

The teacher combined practical skills with theory-based arguments. She did not provide a solution, but instead asked thought-provoking questions ("What's the most important thing?" and "How do you know this? Why?"). She used mistakes as an opportunity for learning, and she gave real feedback; while doing so, she stayed cheerful and added a touch of humor. During the interview, she emphasized the importance of having a good relationship with the students and focusing on their strengths:

One of the students wasn't particularly good at design, but she excelled in drawing. She was radiant while doing it, so I made sure to steer her in that direction. (T1)

She also pointed out that she uses different student pairing and grouping strategies, depending on the goals she has in mind; that is, sometimes she groups together lower- and higher-performing students, and at other times, when she wants students to help one another, she forms mixed-ability groups. Group-formation thus depends on learning objectives. She puts just as much thought into matching students in pairs:

$\mid$\begin{tabular}{l} 
PROBLEMS \\
OF EDUCATION \\
IN THE 21 $1^{\text {st }}$ CENTURY \\
Vol. 78, No. 5, 2020 \\
\hline 823
\end{tabular} 
Klara SKUBIC ERMENC, Damijan ŠTEFANC, Jasna MAŽGON. Challenges of differentiated and individualized teaching in vocational education: The case of Slovenia

PROBLEMS

OF EDUCATION

IN THE $21^{\text {st }}$ CENTURY

Vol. 78, No. 5, 2020

824

Each student is one of a kind. Lesson accommodations are often made through pair work-I often pair lower- and higher-performing students. Students love to help one another. (T1)

The teacher let them act on their own initiative, encouraging them to choose what they would like to do themselves. She only made sure that everyone mastered all the technological procedures. The lessons were therefore differentiated not only according to the students' ability differences but also according to their interests. The teacher also encourages gifted students to enter national and international competitions:

I persuaded a student of mine to enter an international competition. She came on the very same day. She chose all the recipes herself... I only guided her when it came to the decoration. We prepared for the competition outside of class. The student won in the student and adult categories. (T1)

\section{The Second Observed Teaching Unit: Technical Module Class}

In the first 10 minutes of a 45-minute technical module class, the teacher (T2) used the Kahoot! application for individual revision of the learning material. Without a noticeable transition, she moved on to explaining some new learning material using PowerPoint presentations. The students listened to her and made notes in their notebooks. They were given no opportunity to participate; the teacher only occasionally asked, "Are you done? OK!" and "Any questions?" but did not wait for the students to respond. She summarized what they had learned, while the students were writing it down. This was followed by a 10-minute knowledge revision session, during which the students completed worksheets on their own. The teacher walked around the classroom but did not communicate with the students. During the last five minutes, she quickly tested their knowledge, using frontal teaching: the students read the answers, some of which were incomprehensible, but she did not complete them. The lesson was not individualized. The teacher explained,

I was hoping that I would succeed in individualizing the lesson during the revision. But since this was the first time, we were using this program, the app, it just didn't work out. (T2)

She used the Kahoot! application because the observers were present in the classroom. She seemed to view individualization as something that happens by chance and does not require any planning. She added,

This is how I see [individualization]: when we are learning something new, the students study it themselves and then, within their abilities, they tell me how they understood it... This is how I think individualization can be done in this particular school subject. (T2)

She often gives her students homework but does not individualize it. She does not understand the principle of individualization, and she mistakes it for independent learning.

\section{The Third Observed Teaching Unit: Technical Module Class}

This 45-minute technical module class was taught by two teachers (T3, T4) who wanted to present a model lesson in terms of individualization. They assembled their students into four groups, all of which were required to search for certain data using their mobile phones. The groups differed in how difficult their data search method was to use, i.e., differentiation in terms of learning objectives and standards of knowledge could be identified. At the end of the lesson, one of the two teachers explained the following: 
Klara SKUBIC ERMENC, Damijan ŠTEFANC, Jasna MAŽGON. Challenges of differentiated and individualized teaching in vocational education: The case of Slovenia

PROBLEMS

OF EDUCATION

IN THE $21^{\text {st }}$ CENTURY

Vol. 78 , No. 5, 2020

One group achieved a minimum standard of knowledge and three other groups achieved a similar standard of knowledge-of these, one group's standard of knowledge was slightly higher. This 825 means that for the minimum standard, they used a somewhat easier method to search for data on their smartphones. (T4)

Thus, three levels of knowledge standards were covered with four groups. Group work lasted about 20 minutes, the teachers were circulating from one group to another, helping and encouraging the students. This was followed by the students reporting their results, which the teachers noted down using PPT. The teachers said that when it comes to grouping the students, they had some dilemmas-they feared that some students would feel inferior. One of the two teachers concluded,

I have to say that this was the first time we did this... But I'll do it often again because it's both fun and educational... And it keeps them entertained. (T3)

The two teachers showed a superficial understanding of the principle of individualization; they did not have any previous experience with it, which might explain why they were inept and insecure.

\section{Satisfaction and Students' Assessments}

Students were asked about their level of satisfaction with the choice of their school or program, with the technical module lessons, and with the practical classes. Table 3 reveals that the students are for the most part satisfied or very satisfied with their choice of school and the classes at the school. The highest satisfaction assessment was given for the practical classes-as many as $45 \%$ of the students are very satisfied with them, while a little over $18 \%$ of the students are very satisfied with the technical module class.

\section{Table 3}

Satisfaction with various aspects of schooling $(N=22)$

\begin{tabular}{|c|c|c|c|c|c|c|}
\hline $\begin{array}{l}\text { Satisfaction with Various } \\
\text { Aspects of Schooling }\end{array}$ & $\begin{array}{l}\text { Very } \\
\text { Dissatisfied }\end{array}$ & Dissatisfied & Neutral & Satisfied & $\begin{array}{l}\text { Very } \\
\text { Satisfied }\end{array}$ & Total \\
\hline $\begin{array}{l}\text { Satisfaction with the } \\
\text { choice of school }\end{array}$ & $2(9.1)$ & $0(0.0)$ & $1(4.5)$ & $12(54.5)$ & $7(31.8)$ & $22(100.0)$ \\
\hline $\begin{array}{l}\text { Satisfaction with the } \\
\text { technical module } \\
\text { classes }\end{array}$ & $0(0.0)$ & $0(0.0)$ & $3(13.6)$ & 15 (68.2) & $4(18.2)$ & $22(100.0)$ \\
\hline $\begin{array}{l}\text { Satisfaction with the } \\
\text { practical classes }\end{array} \quad f(\%)$ & $1(5.0)$ & $0(0.0)$ & $3(15.0)$ & $7(35.0)$ & $9(45.0)$ & $20(100.0)$ \\
\hline
\end{tabular}

The students were asked about the frequency of those classroom activities through which individualized teaching can be realized. Table 4 shows that most classes involve the students copying the learning content from a board or projection screen or writing it down according to the teacher's dictation. Teachers often prepare lesson summaries and the students often work with one another. Learning by means of videos and completing worksheets is also present to a relatively large extent. According to the students, project work, group work, and pair work, and completing tasks with the help of computer technology, including smartphones, is less common. The least common lesson component involved several teachers working together, except in practical classes, where students from one class were divided into two smaller groups. 
Klara SKUBIC ERMENC, Damijan ŠTEFANC, Jasna MAŽGON. Challenges of differentiated and individualized teaching in vocational education: The case of Slovenia

PROBLEMS

OF EDUCATION IN THE $21^{\text {st }}$ CENTURY Vol. 78 , No. 5, 2020

826

The results indicate that the teachers lead the students as a group towards their goals (in a nondifferentiated way); in doing so, they have control over the learning content, presenting it to the students step by step.

Table 4

Didactic lesson features according to the students (in \%; $N=22$ )

\begin{tabular}{lll}
\hline Didactic lesson features*: & Technical module class & Practical class \\
\hline Students copy the learning content from a board or projection screen. & 90.0 & 90.0 \\
\hline Students work with one another. & 82.0 & 100.0 \\
\hline $\begin{array}{l}\text { Students write down learning content according to the teacher's } \\
\text { dictation. }\end{array}$ & 81.9 & 85.8 \\
\hline Teachers prepare lesson summaries. & 80.0 & 95.3 \\
\hline Teachers use presentations prepared in advance. & 80.0 & 66.7 \\
\hline Teachers use videos. & 77.2 & 81.8 \\
\hline Students complete worksheets. & 73.0 & 72.2 \\
\hline Students work on projects. & 63.7 & 75.0 \\
\hline Students complete exercises using computer technology. & 57.2 & 54.5 \\
\hline Classes are held in small groups or pairs. & 54.6 & 68.2 \\
\hline Students complete exercises using smartphones. & 42.0 & 62.0 \\
\hline Multiple teachers are involved in the lesson. & 19.0 & 50.0 \\
\hline Note * Combined “often" and "very often" assessments & &
\end{tabular}

The biggest differences between technical module classes and practical classes can be noticed in terms of the students' cooperation and in terms of the classes being held in small groups and pairs. Group and pair work are more common in practical classes, whereas in technical module classes, teachers often use presentations prepared in advance (to explain new learning content), while in practical classes there is more project work.

\section{Discussion}

The school views individualization as a measure that is implemented mostly at the level of individual classes and teachers. No specific individual learning plans are being prepared for students at the school or program level that support them to follow their individual learning paths more effectively. As emphasized by Solberg et al. (2012), such plans-if properly introduced-may contribute to the students' engagement "in self-initiated learning by managing and selecting courses and other educational and learning opportunities that support their ability to successfully realize their future aspirations" (Solberg et al., 2012, p. 502). Similarly, based on their study, Muñoz Martínez and Porter (2018) suggested that personalized learning plans could improve inclusive orientation of education and provide the teacher with "the opportunity to identify the most appropriate avenue to meet the needs of each student" (Muñoz Martínez \& Porter, 2018, p. 14).

However, this does not mean that the school fails completely to respond to the students' diversity. On the contrary, many responses were observed, as well as a great deal of care and even concern for the students' living conditions and the problems they face. However, since the school keeps no records of the kind (and thus does not have a clear understanding of the situation as a whole), these responses are often random and less systematic. More systematicand planned on an annual basis-is the school's work in the areas where they have certain statutory commitments (education of students with statements of special educational needs); however, the school's response was also noticeable in cases where additional funds are provided 
PROBLEMS

OF EDUCATION

IN THE $21^{\text {st }}$ CENTURY

Vol. 78 , No. 5, 2020

by the Ministry (e.g., funds for lessons that are part of the Slovenian language courses for newly immigrated students). Similarly, the school has various pre-arranged mechanisms for certain groups of students that have a special status (such as student athletes) and gifted students, especially in terms of preparations for national and international competitions. Other activities are organized when necessary and are considered corrective measures, such as learning support provided to students who do not meet the expected standards or support for students who find themselves in a difficult social situation or have intellectual disabilities.

Likewise, consistent with the school management's belief that individualization is a measure that is implemented at the class level are the forms of support the management provides to the teachers. The support is focused on class teachers, as they are the ones that have a more active educational role in relation to the students. In addition to performing various legal-formal tasks, class teachers are in charge of caring for the students' wellbeing. With this in mind, the school management organizes and promotes various activities, such as mutual learning and teacher-class teacher cooperation, encouraging them to organize peer support and monitor student progress. The teachers undertake these activities voluntarily-they are not required to do so and the management does not check how well the activities are organized, which is clear from the HT's statement: "If they feel like it, the class teachers are welcome to keep records, but they can choose not to."

The school management encourages teachers and class teachers, providing them with an environment that allows cooperation; however, it does not require them to assume responsibility for taking care of each individual student. The level of engagement depends on the teacher's or class teacher's willingness. Based on the observation of lessons-albeit a limited number of them-and students' assessments, the following three insights can be noted regarding the didactic features of lessons:

(1) In terms of individualization and internal differentiation, the quality of teaching depends on the knowledge, beliefs, and enthusiasm of each individual teacher. Thus, an example of a very high-quality practical class was observed, as well as quite the opposite (both technical module classes). In practical classes, the teacher adapted the standards of knowledge, the pace of learning, and the level of independent work to the students. The teacher grouped the students according to the goals they wanted to work towards, focused on the students' strengths, encouraged theory-based arguments in support of a certain procedure, created a positive work environment, and gave encouraging and meaningful feedback. The teacher also took into account the differences in the students' interest and gave more challenging tasks to gifted students. These methods are in line with individualizing practices noted by several other researchers (Bešić et al., 2016; Yngve et al., 2018; Westwood, 2003).

(2) Understandably, the results of the student questionnaire cannot detect the differences among individual teachers. They do, however, reveal that the students were very satisfied with the lessons and the school. This encouraging result can be understood in light of the school's efforts, which are-according to the school management and the school counselling serviceaimed at solving the students' personal, social and learning-related problems. It looked like the students felt safe and accepted at school. There was, however, a downside to this care and attentiveness, and at times even pity (Fulcher, 1989) because the teachers do not expect much from most students in terms of education. This is evident from the technical module class observation and the questionnaires: teachers guide students through the learning process step by step, using steps that are carefully planned in advance and teaching materials that do not require much independence, creativity, and resourcefulness in less predictable occupational situations. In addition, the usage of information and communication technology (ICT) seems to be quite limited: although the available technology would allow for more intensive interactive work with the ICT, the results raise questions about whether teachers are skilled enough to efficiently adapt ICT to achieve educational goals, as emphasized more than a decade ago by Lamanauskas (2008, p. 7). 
Klara SKUBIC ERMENC, Damijan ŠTEFANC, Jasna MAŽGON. Challenges of differentiated and individualized teaching in vocational education: The case of Slovenia

PROBLEMS

OF EDUCATION IN THE $21^{\text {st }}$ CENTURY Vol. 78, No. 5, 2020

828

(3) Although the school devotes considerable attention to how best to respond to a diverse student population and uses a number of different activities/mechanisms, the focus of its actions is largely on activities that take place outside of class (learning support) and the potential of the actual lessons seems to be largely unexploited. The teachers do not understand individualization in its entirety. For the most part, it is limited to their readiness to help the students, and they fail to view it as a fundamental teaching philosophy, which would be reflected in common guidelines and activities.

\section{Conclusions and Implications}

A revealing insight into the core of one vocational school and one class within the school has important implications for systemic issues. Overall, the school responds to the needs of students, especially those from the most vulnerable groups. However, the lack of clear data shows that the school has no systematic and comprehensive approach and therefore responds to challenges whenever they come up, focusing on solving the most serious problems.

The results illustrate the consequences of the existing differentiation model at the upper secondary level of education in a country that is formally based on transition, the principle of lifelong learning, and labor market needs, while in reality, it functions as a mechanism of social reproduction. All schools that are in a similar situation as the school analyzed face challenges because their mission goes beyond an educational role, taking on a social-integration one as well. The school must demand appropriate tangible and intangible support from decision-makers to be able to place individualization at the core of its work. However, for this to happen, the school needs to move away from understanding individualization as a measure adopted at the teachingexecution level by individual teachers. By raising the understanding of individualization to the level of the school as an institution, teachers can receive guidance on how to guide each student through the course of education in a way that makes sure the path is adapted to their individual characteristics and aspirations as well as it can be. This shift in understanding would allow teachers to use individualization in a significantly more effective way.

\section{Acknowledgements}

The authors acknowledge the financial support from the Slovenian Research Agency (research core funding No P5-0174 Pedagogical and Andragogical Studies-Learning and Education for a Good Quality Life in Community), and the financial support by the Operational Programme for the Implementation of the EU Cohesion Policy in the period 2014-2020: The project Modernizing Vocational Education and Training System, Institute of the Republic of Slovenia for Vocational Education and Training (CPI).

\section{References}

Arduin, S. (2015). A review of the values that underpin the structure of an education system and its approach to disability and inclusion. Oxford Review of Education, 41(1), 105-121. https://doi.org/10.1080/03054985.2015.1006614

Belasić, I., \& Čop, J. (2020). Individualizacija v programih srednjega poklicnega izobraževanja. Prvo poročilo o rezultatih empirične raziskave na pilotnih šolah v projektu MIND+ [Individualization in secondary vocational education programs. The first report on the results of empirical research in pilot schools in the MIND + project.] Center RS za poklicno izobraževanje. [Institute of the Republic of Slovenia for Vocational Education and Training].

Brancati, D. (2018). Social scientific research. Sage.

Bushie, C. (2015). Literature review: Differentiation in education. Journal of Graduate Studies in Education, 7(2), 35-42. https://www.brandonu.ca/master-education/files/2010/07/BU-Journalof-Graduate-Studies-in-Education-2015-vol-7-issue-2.pdf 
Klara SKUBIC ERMENC, Damijan ŠTEFANC, Jasna MAŽGON. Challenges of differentiated and individualized teaching in vocational education: The case of Slovenia

Cankar, G., Bren, M., \& Zupanc, D. (2017). Za večjo pravičnost šolskega sistema v Sloveniji. Analize povezav dosežkov učenk in učencev s socialnimi, kulturnimi, ekonomskimi in regionalnimi značilnostmi učenk in učencev, pridobljenimi prek podatkov Statističnega urada RS. [For greater justice of the school system in Slovenia. Analyses of the connections of students' achievements with the social, cultural, economic and regional characteristics of students obtained through data from the Statistical Office of the Republic of Slovenia.] Državni izpitni center [National Examination Centre].

CEDEFOP (2017). Pregled vajeništva: Slovenija. Uvajanje vajeništva v Sloveniji. Tematski pregledi po državah. [Apprenticeship overview: Slovenia. Introduction of apprenticeships in Slovenia. Thematic reviews by countries.] Urad za publikacije Evropske unije. [Publications Office of the European Union.]. https://www.cedefop.europa.eu/files/4157_sl.pdf

Deunk, M. I., Smale-Jacobse, A. E., de Boer, H., Doolaard, S., \& Bosker, R. J. (2018). Effective differentiation practices: A systematic review and meta-analysis of studies on the cognitive effects of differentiation practices in primary education. Educational Research Review, 24, 3154. https://doi.org/10.1016/j.edurev.2018.02.002

Dixon, F. A., Yssel, N., McConnell, J. M., \& Hardin, T. (2014). Differentiated instruction, professional development, and teacher efficacy. Journal for the Education of the Gifted, 37(2), 111-127. https://doi.org/10.1177/0162353214529042

Dupriez, V. (2010). Methods of grouping learners at school. United Nations.

Ermenc, K. S. (2009): From de-tracking to re-tracking in Slovenian upper secondary education. In J. Hopfner \& E. Protner (Eds.), Education from the past to the present: Pedagogical and didactic lessons from the history of education (pp. 122-138). Filozofska fakulteta, Mednarodna založba Oddelka za slovanske jezike in književnosti.

Ermenc, K. S. (2011). Vocational education and training in Slovenia between 1974 and 2010: developments and dilemmas. In J. B. Holen \& A. L. Phillips (Eds.), Studies in education from diverse contexts (pp. 11-26). College of Education and Human Development, University of North Dakota.

Fulcher, G. (1989). Disabling policies? A comparative approach to education policy and disability. The Falmer Press.

Gregory, G. H., \& Chapman, C. (2002). Differentiated instructional strategies: One size doesn't fit all. Corwin Press.

Yngve, M., Lidström, H., Ekbladh, E., \& Hemmingsson, H. (2018). Which students need accommodations the most, and to what extent are their needs met by regular upper secondary school? A crosssectional study among students with special educational needs. European Journal of Special Needs Education, 34(3), 327-341. https://doi.org/10.1080/08856257.2018.1501966

Humphrey, N., Wigelsworth, M., Barlow, A., \& Squires, G. (2013). The role of school and individual differences in the academic attainment of learners with special educational needs and disabilities: A multi-level analysis. International Journal of Inclusive Education, 17(9), 909931. https://doi.org/10.1080/13603116.2012.718373

Kalin, J. (2001). Pogledi na razrednikovo delo in vloge razrednika. [Views on the class teacher's work and the role of the class teacher.] Sodobna pedagogika, 52(1), 8-31.

Konzorcij projekta Included. (2010). Analiza dobrih praks $v$ evropskih šolskih sistemih. [Consortium of the project Included (2010). Analysis of good practices in European school systems.] Andragoški center Slovenije. https://arhiv.acs.si/publikacije/Analiza_dobrih_praks_v_evropskih_solskih_ sistemih.pdf

Kroflič, R., Klarič, T., \& Peček Čuk, M. (Eds.). (2009). Ali poklicne in strokovne šole potrebujejo vzgojni koncept? [Do vocational and technical schools need an educational concept?] Center RS za poklicno izobraževanje. [Institute of the Republic of Slovenia for Vocational Education and Training].

Kubat, U. (2018). Identifying the individual differences among students during learning and teaching process by science teachers. International Journal of Research in Educational and Science, 4(1), 30-38. https://www.ijres.net/index.php/ijres/article/view/299/pdf 
Klara SKUBIC ERMENC, Damijan ŠTEFANC, Jasna MAŽGON. Challenges of differentiated and individualized teaching in vocational education: The case of Slovenia

PROBLEMS

OF EDUCATION

IN THE $21^{\text {st }}$ CENTURY Vol. 78, No. 5, 2020

830

Lamanauskas, V. (2008). Effective ICT implementation as a precondition for developing general and vocational education. Problems of Education in the 21st Century, 5, 5-8. http://oaji.net/articles/2014/457-1392223337.pdf

Lamanauskas, V. (2009). Integrated science teaching by applying didactic differentiation: Some actual circumstances. Problems of Education in the 21st Century, 13, 5-12. http://oaji.net/ articles/2014/457-1393665879.pdf

LeTendre, G. K., Hofer, B. K., \& Shimizu, H. (2003). What is tracking? Cultural expectations in the United States, Germany, and Japan. American Educational Research Journal, 40(1), 43-89. https://doi.org/10.3102/00028312040001043

Medveš, Z., Kodelja, Z., Mažgon, J., Ermenc, K. S., Peček, M., Lesar, I., \& Pevec Grm, S. (2008). Prispevek poklicnega in strokovnega izobraževanja $\mathrm{k}$ pravičnosti in socialni vključenosti. [Contribution of vocational education and training to equity and social inclusion.] Sodobna pedagogika, 59(5), 74-94.

Medveš, Z., \& Muršak, J. (Eds.). (1992). Sistemsko urejanje poklicnega izobraževanja. [Regulation of the system of vocational education.] Slovensko društvo pedagogov. Andragoško društvo Slovenije. Ministrstvo za šolstvo in šport. [Slovenian Association of Educators, Andragogical Society of Slovenia, Ministry of Education and Sports].

MIZŠ. (2019). Podatki z analizo za srednje šole in dijaške domove (šolsko leto 2017/2018). [Data for secondary schools and student dormitories with analysis (school year 2017/2018)]. Ministrstvo za izobraževanje, znanost in šport. Direktorat za srednje in višje šolstvo ter izobraževanje odraslih.

Muñoz Martínez, Y., \& Porter, L. G. (2018). Planning for all students: Promoting inclusive instruction. International Journal of Inclusive Education, 22, 1-16. https://doi.org/10.1080/13603116.2018.1544301

Oakes, J. (2005). Keeping track: How schools structure inequality. Yale University Press.

Poročilo o spremljanju individualizacije in diferenciacije pedagoškega procesa. (2008). [Report on monitoring the individualization and differentiation of the pedagogical process. (2008).] Center RS za poklicno izobraževanje. [Institute of the Republic of Slovenia for Vocational Education and Training].

Slavin, R. E. (1987). Ability grouping and student achievement in elementary schools: A best-evidence synthesis. Review of Educational Research, 57(3), 293-336. https://doi.org/10.3102/00346543057003293

Slavin, R. E.(1990). Achievementeffects of ability grouping in secondary schools:Abest-evidence synthesis. Review of Educational Research, 60(3), 471-499. https://doi.org/10.3102/00346543060003471

Solberg, V. S., Phelps, L. A., Haakenson, K. A., Durham, J. F., \& Timmons, J. (2012). The nature and use of individualized learning plans as a promising career intervention strategy. Journal of Career Development, 39(6), 500-514. https://doi.org/10.1177/0894845311414571

Stanojević, M., \& Furlan, S. (Eds.). (2018). (Ne) dostojno delo. Prekarizacija standardnega in nestandardnega zaposlovanja v Sloveniji. [(In) decent work. Precarization of standard and nonstandard employment in Slovenia]. Fakulteta za družbene vede, Založba FDV.

Statistični urad Republike Slovenije. (2019). Tudi v šolskem letu 2018/19 osnovnošolcev več, srednješolcev pa nekaj manj kot v preteklih letih. [Statistical Office of Slovenia. (2019). Also in the 2018/19 school year, there are more primary school students and slightly fewer secondary school students than in previous years]. https://www.stat.si/StatWeb/News/Index/8144

Strmčnik, F. (1987). Sodobna šola v luči učne diferenciacije in individualizacije. [Modern school in the light of learning differentiation and individualization.] Zveza organizacij za tehnično kulturo Slovenije.

Strmčnik, F. (1999). Učna diferenciacija bodoče osnovne šole v luči kritike. [Learning differentiation of the future primary school in the light of criticism.] Sodobna pedagogika, 50(1), 52-71.

Subban, P. (2006). Differentiated instruction: A research basis. International Education Journal, 7(7), 935-947. https://files.eric.ed.gov/fulltext/EJ854351.pdf

Thomas, G. (2013). A review of thinking and research about inclusive education policy, with suggestions for a new kind of inclusive thinking. British Educational Research Journal, 39(3), 473-490. https://doi.org/10.1080/01411926.2011.652070 
Klara SKUBIC ERMENC, Damijan ŠTEFANC, Jasna MAŽGON. Challenges of differentiated and individualized teaching in vocational education: The case of Slovenia

Tomlinson, C. A. (2001). How to differentiate instruction in mixed-ability classrooms. Association for Vol. 78 , No. 5, 2020 Supervision and Curriculum Development.

Vižintin, M. A. (2017). Medkulturna vzgoja in izobraževanje. Vključevanje otrok priseljencev. [Intercultural education. Inclusion of immigrant children]. Založba ZRC SAZU.

Wang, M. C., \& Lindvall, C. M. (1984). Individual differences and school learning environments. Review of Research In Education, 11(1), 161-225. https://doi.org/10.3102/0091732X011001161

Westwood, P. (2003). Commonsense methods for children with special educational needs. Routledge Falmer.

Willms, J. D. (2006). Learning divides: Ten policy questions about the performance and equity of schools and schooling systems. UNESCO Institute for Statistics.

Received: June 09, 2020

Accepted: October 02, 2020

Cite as: Skubic Ermenc, K., Štefanc, D., \& Mažgon, J. (2020). Challenges of differentiated and individualized teaching in vocational education: The case of Slovenia. Problems of Education in the $21^{\text {st }}$ Century, 78(5), 815-831. https://doi.org/10.33225/pec/20.78.815

\begin{tabular}{|c|c|}
\hline Klara Skubic Ermenc & $\begin{array}{l}\text { PhD, Associate Professor, University of Ljubljana, Faculty of Arts, Aškerčeva 2, } \\
\text { SI-1000 Ljubljana, Slovenia. } \\
\text { E-mail: klara.skubic-ermenc@ff.uni-lj.si } \\
\text { Website: http://www.ff.uni-lj.si/an/study/departments/department_educational_ } \\
\text { sciences } \\
\text { ORCID: https://orcid.org/0000-0003-3153-7540 }\end{array}$ \\
\hline $\begin{array}{l}\text { Damijan Štefanc } \\
\text { (Corresponding author) }\end{array}$ & $\begin{array}{l}\text { PhD, Associate Professor, University of Ljubljana, Faculty of Arts, Aškerčeva 2, } \\
\text { SI-1000 Ljubljana, Slovenia. } \\
\text { E-mail: damijan.stefanc@ff.uni-lj.si } \\
\text { Website: http://www.ff.uni-lj.si/an/study/departments/department_educational_ } \\
\text { sciences } \\
\text { ORCID: https://orcid.org/0000-0003-0714-8684 }\end{array}$ \\
\hline Jasna Mažgon & $\begin{array}{l}\text { PhD, Associate Professor, University of Ljubljana, Faculty of Arts, Aškerčeva 2, } \\
\text { SI-1000 Ljubljana, Slovenia. } \\
\text { E-mail: jasna.mazgon@ff.uni-lj.si } \\
\text { Website: http://www.ff.uni-lj.si/an/study/departments/department_educational_ } \\
\text { sciences } \\
\text { ORCID: https://orcid.org/0000-0002-9594-4674 }\end{array}$ \\
\hline
\end{tabular}

